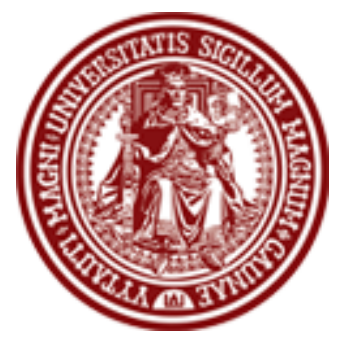

BALTIC JOURNAL OF LAW \& POLITICS

VOLUME 5, NUMBER 1 (2012)

ISSN 2029-0454

http://www.versita.com/bjlp

Cit.: Baltic Journal of Law \& Politics 5:1 (2012): 20-45

DOI: $10.2478 / \mathrm{v} 10076-012-0002-2$

\title{
TOWARDS PRESIDENTIAL RULE IN UKRAINE: HYBRID REGIME DYNAMICS UNDER SEMI-PRESIDENTIALISM
}

\author{
Thomas Sedelius \\ Associate Professor \\ Dalarna University, School of Health and Social Science (Sweden) \\ Contact information \\ Address: SE-791 88 Falun, Sweden \\ Phone: +46 23778451 \\ E-mail address: tse@du.se
}

\section{Sten Berglund}

Professor

Örebro University, School of Humanities, Education and Social Sciences (Sweden)

Contact information

Address: SE-701 82 Örebro, Sweden

Phone: +4619303860

E-mail address: sten.berglund@oru.se

Received: April 16, 2012; reviews: 2; accepted: May 21, 2012.

\section{ABSTRACT}

This article sets out to analyse recent regime developments in Ukraine in relation to semi-presidentialism. The article asks: to what extent and in what ways theoretical arguments against semi-presidentialism (premier-presidential and president-parliamentary systems) are relevant for understanding the changing directions of the Ukrainian regime since the 1990s? The article also reviews the by now overwhelming evidence suggesting that President Yanukovych is turning Ukraine into a more authoritarian hybrid regime and raises the question to what extent the president-parliamentary system might serve this end.

The article argues that both kinds of semi-presidentialism have, in different ways, exacerbated rather than mitigated institutional conflict and political stalemate. The return to 
the president-parliamentary system in 2010 - the constitutional arrangement with the most dismal record of democratisation - was a step in the wrong direction. The premierpresidential regime was by no means ideal, but it had at least two advantages. It weakened the presidential dominance and it explicitly anchored the survival of the government in parliament. The return to the 1996 constitution ties in well with the notion that President Viktor Yanukovych has embarked on an outright authoritarian path.

\section{KEYWORDS}

Ukraine, constitution, semi-presidentialism, premier-presidentialism, presidentparliamentarism, hybrid regime 


\section{INTRODUCTION}

The last round of the 2010 presidential elections put an abrupt end to Ukraine's Orange Revolution. The undisputed winner was Viktor Yanukovych, the leader of the Party of Regions, whose attempts to steal the previous presidential elections had been thwarted by the Orange Revolution of 2004. The five years inbetween were dominated by political tensions between the two opposing camps but also within the winning coalition. The leaders of the Orange Revolution, President Viktor Yushchenko and his sometime Prime Minister, Yulia Tymoshenko, were more often than not on a course of confrontation and ended up running on separate tickets in 2010.

But the impact of the Orange Revolution was positive in so far as it broke the hybrid deadlock in Ukrainian politics and reinitiated the process of democratisation. The response of the international community was favourable. Freedom House promptly included Ukraine among the democracies of the world and Ukraine was to defend this unique position within the Russian sphere of influence through the presidential elections of 2010, but this trend was not to be lasting. A year later, Freedom House once again rated Ukraine as only "partly free".

The constitutional framework in hybrid regimes is crucial as an arena where the political incumbents struggle to define and expand their influence. The political opposition has accused the Yanukovych regime of having a secret rollback strategy designed to re-establish the strong presidency of the Kuchma regime - suspicions echoed by international media. The president-parliamentary constitution of 1996 to which Ukraine returned in 2010 - is of the standard post-Soviet variety with a strong president and a weak parliament. It has a dismal record as an agent of democratisation and many comparativists therefore strongly advise against it. ${ }^{1}$ The kind of premier-presidentialism practised under Yushchenko (2006-2010) introduced a division of power strengthening the role of the prime minister and the parliament and weakening that of the president. This paved the way for a more dualistic political system as it explicitly balances between two domains of executive power - one for the president and one for the prime minister. Under the restored constitution of 1996 the prime minister is clearly subordinated to the president and as such it provides for one dominant pillar of executive power.

In this article we set out to analyse recent regime developments in Ukraine in relation to its semi-presidential structure. We ask: to what extent and in what ways

\footnotetext{
${ }^{1}$ E.g. Robert Elgie, Semi-Presidentialism: Sub-Types and Democratic Performance (Oxford: Oxford University Press, 2011); David J. Samuels and Matthew S. Shugart, Presidents, Parties, and Prime Ministers: How the Separation of Powers Affects Party Organization and Behavior (New York: Cambridge University Press 2010).
} 
are conventional arguments against semi-presidentialism (premier-presidential and president-parliamentary systems) relevant for understanding the shifting directions of the Ukrainian regime since the late 1990s? In this process, we will also review the by now overwhelming evidence suggesting that President Yanukovych is turning Ukraine into a more authoritarian hybrid regime and raise the question to what extent the president-parliamentary system might serve this end.

The article starts by defining semi-presidentialism and by outlining some key theoretical arguments on the pros and cons of premier-presidential and presidentparliamentary systems. Next, we place Ukraine in its broader post-Soviet context as a hybrid regime balancing between democratic and authoritarian features. In the subsequent empirical analysis, we identify and discuss institutional conflicts and political stalemate in Ukraine in light of its two semi-presidential systems. Finally, in the concluding section, we draw together the main findings of our analysis and make some general remarks on the current regime direction in Ukraine.

\section{SEMI-PRESIDENTIALISM: DEFINITION AND THEORETICAL}

\section{ARGUMENTS}

Ukraine was by no means the only post-Soviet state to adopt a semipresidential system with a strong presidency after independence. With the exception of Turkmenistan (presidential), Estonia, and Latvia (parliamentary), semi-presidential constitutions were in fact installed throughout the former Soviet Union $^{2}$. Semi-presidentialism came about almost by default and as a natural bargaining outcome, as it represents a compromise between pure parliamentarism and pure presidentialism. It also offers a level of flexibility and scope for negotiation over the relative powers of president, prime minister and parliament. ${ }^{3}$

Semi-presidentialism of the variety known as president-parliamentary ${ }^{4}$ was the preferred choice of the vast majority of former Soviet republics, including Ukraine. ${ }^{5}$ Applying a strictly constitutional definition of semi-presidentialism ${ }^{6}$ and

\footnotetext{
2 Robert Elgie and Sophia Moestrup, eds., Semi-Presidentialism in Central and Eastern Europe (Manchester: Manchester University Press 2008).

3 Sara Birch, "Semi-Presidentialism in Ukraine"; in: Robert Elgie and Sophia Moestrup, eds., SemiPresidentialism in Central and Eastern Europe (Manchester: Manchester University Press 2008).

${ }^{4}$ Matthew S. Shugart and John M. Carey, Presidents and Assemblies: Constitutional Design and Electoral Dynamics (New York: Cambridge University Press 1992); Thomas Sedelius, "Demokrati eller presidentdiktatur: Konstitutionella vägval i postkommunistiska länder," Nordisk Østforum 22:8 (2008): 142-161.

${ }^{5}$ Already before the formal declaration of Ukrainian independence (August 1991), a presidency was created (July 1991). The rapid disintegration of the Soviet Union and the shift of power to the republics inspired the creation of a presidential institution, as it was hoped that a presidency would enhance the strengthening of the institutional resources and the self-governing capacity of the Ukrainian republic.

${ }^{6} \mathrm{~A}$ quite substantial literature has been devoted to the concept of semi-presidentialism and the classical definition by Maurice Duverger (1980) has been reformulated and somewhat criticised over time (e.g. Robert Elgie, "The Classification of Democratic Regime Types: Conceptual Ambiguity and Contestable Assumptions," European Journal of Political Research 33:2 (1998); Robert Elgie, "Duverger, Semi-
} 
distinguishing between president-parliamentary and premier-presidential systems, we define a president-parliamentary system as a system where (1) the president is elected by a popular vote for a fixed term in office; (2) the president appoints and dismisses the prime minister and other cabinet ministers; (3) the prime minister and cabinet ministers are subjected to parliamentary as well as presidential confidence; and (4) the president typically has some legislative powers and the power to dissolve the parliament. Premier-presidentialism prevails where (1) the president is elected by a popular vote for a fixed term in office; (2) the president selects the prime minister who heads the cabinet; but (3) authority to dismiss the cabinet rests exclusively with the parliament. ${ }^{7}$ Hence, an important difference between president-parliamentary and premier-presidential systems is that in the former the government is accountable to both the president and the parliament, whereas in premier-presidential systems the government is accountable only to the parliament. In addition, and just as important, president-parliamentary systems are generally characterised by stronger presidential prerogatives.

The Ukrainian constitution of 1996 features the typical characteristics of a president-parliamentary system, including a directly elected president with a first say on cabinet formation and executive matters, and a cabinet subordinated to presidential as well as parliamentary confidence. Less typical, though, the Ukrainian president was not vested with the authority to dissolve the parliament, neither before, nor after the adoption of the 1996 constitution. With the constitutional amendments of 2004, the system shifted towards premier-presidentialism (in force 2006-10). The presidential prerogatives were drastically curtailed and the government was explicitly described as dependent upon parliamentary support alone.

The power balance in favour of the president in the 1996 constitution becomes apparent by considering the formal presidential powers. Based on criteria originally developed by Shugart and $\mathrm{Carey}^{8}$, Elgie and Moestrup have assessed the formal powers of the presidencies in a number of Central and East European

Presidentialism and the Supposed French Archetype," West European Politics 32:2 (2009); Steven D. Roper "Are All Semipresidential Regimes the Same: A Comparison of Premier-Presidential Regimes," Comparative Politics 34:3 (2002); Alan Siaroff, "Comparative Presidencies: The Inadequacy of the Presidential, Semi-Presidential and Parliamentary Distinction," European Journal of Political Research 42:3 (2003).

7 Maurice Duverger, "A New Political System Model: Semi-presidential Government," European Journal of Political Research 8 (1980); Matthew S. Shugart and John M. Carey, supra note 4, p. 23-24; Matthew Shugart, "Semi-presidential Systems: Dual Executive and Mixed Authority Patterns," French Politics 3:3 (2005).

${ }^{8}$ Shugart and Carey, 1992, developed a scheme for measuring presidential power including legislative powers (package veto, partial veto, decree, introduction of legislation, budgetary policy influence, and referenda) and non-legislative powers (cabinet formation, cabinet dismissal, censure, and dissolution of parliament). 
countries. $^{9}$ In their assessment, only Belarus and Russia have stronger powers vested in their presidents than Ukraine. In fact, the 1996 Ukrainian constitution is very close to that of Russia in terms of presidential prerogatives. Their coding also reveals that the constitutional reform after the Orange revolution reduced presidential powers to the average level of Central European premierpresidentialism. The decrease in presidential prerogatives related to cabinet formation and dismissal is particularly conspicuous in their assessment ${ }^{10}$.

In different ways, the scholarly arguments against semi-presidentialism address the risk and consequences of intra-executive (president and government) and executive-legislative (president/government-parliament) conflicts.

Dual legitimacy and institutional conflict. A rather positive (although mainly theoretical) assumption with regard to semi-presidentialism is that the respective roles of the dual executive, the president and the prime minister, are complementary and clearly defined in practice and theory: the president upholds popular legitimacy and represents the continuity of state and nation, while the prime minister exercises policy leadership and takes responsibility for the day-today functions of government. ${ }^{11}$ But the existence of two separately chosen chief executives also implies a situation of "dual legitimacy" - i.e. both the president and the prime minister (although indirectly) can claim authority on a popular mandate and thus the potential for conflict over powers and prerogatives. This conflict potential is exacerbated in a transitional context where the distribution of authority is often ambiguous and fluid. Constitutions in transitional countries generally provide a broad framework for the exercise of power, but without precedents and long-established conventions that define the boundaries between key institutions more precisely. The constitutional framework of semi-presidentialism has thus become a terrain on which institutions and their leaders, in particular presidents and prime ministers, have struggled to define their influence.

Juan Linz was among the first to systematically criticise both presidentialism ${ }^{12}$ and semi-presidentialism ${ }^{13}$. On semi-presidentialism, he warned that conflicts and intrigues between the president and the prime minister may lead to delays and contradictions in policy making. Linz argued that the dual executive structure may

\footnotetext{
${ }^{9}$ Robert Elgie and Sophia Moestrup, supra note 2, p. 252-53. The total score for presidential powers in Ukraine's 1996 constitution is in their calculation 13p, which is close to Russia's 1993 constitution with $14 \mathrm{p}$, but still considerably lower than the extreme case of Belarus' 1996 constitution with 19p. The premier-presidential constitution of Ukraine 2006-10 scored considerably lower than the 1996 one, with a total of 6p, which is similar to that of e.g. Poland's 1997 constitution with 8p, and Romania's 1991 constitution with $7 p$.

${ }_{10}$ Powers on cabinet formation and dismissal dropped from $5 p$ in the 1996 constitution to 0 in the 200610 constitution (Robert Elgie and Sophia Moestrup, supra note 2, p. 252-53).

${ }_{11}$ E.g. Maurice Duverger, supra note 7.

12 Juan J. Linz, "The Perils of Presidentialism," Journal of Democracy 1 (1990).

13 Juan J. Linz, "Presidential or Parliamentary Democracy: Does it Make a Difference"; in: Juan J. Linz and Arturo Valenzuela, eds., The Failure of Presidential Democracy: Comparative Perspectives (Baltimore: Johns Hopkins University Press, 1994).
} 
institutionalise conflict between the president and the government, especially in periods of cohabitation (i.e. when the president's party is not part of the government), leading the president to assume power in order to break the deadlock or to a complete stalemate threatening regime stability. ${ }^{14}$ The most difficult situations are likely to arise under a stalemated party system in which there is a very unstable (or no) majority in the parliament. An already weak party system may be further undermined by a president seeking to govern against, or if possible, without parliament. In accordance with Linz' arguments for parliamentarism over presidentialism, other scholars have stressed the importance of a strong and coherent parliamentary arena and a consolidated party system in order for semipresidential democracies to avoid the risk of presidential dictatorship. ${ }^{15}$

President-parliamentarism is particularly perilous. Following previous studies, the president-parliamentary system has fared particularly poorly in terms of democratisation both among the post-communist countries ${ }^{16}$ and beyond. ${ }^{17}$ In fact, Shugart and Carey explicitly warned constitution-makers "to stay away from president-parliamentary designs". ${ }^{18}$ The arguments against this form of government largely revolve around the dependent and uncertain political position of the government as it is constitutionally "squeezed" between the president and the parliament for its survival. If the president does not have the support of a parliamentary majority, the dual loyalty of the government - to the president and to the parliament - is bound to produce conflict and political stalemate. ${ }^{19}$ The president always retains the option to dismiss the prime minister in an attempt to break the political stalemate. But the appointment of a new prime minister candidate requires the support of the parliament and the president may find that the relationship with the new prime minister is just as troublesome, if not more so because of the crisis caused by the dismissal of his or her predecessor. Since both the president and the parliament retain the power to dismiss the government, each institution may calculate that the best way to maximise influence is to work against rather than with the other institution. Such conflicts over appointments and

\footnotetext{
${ }^{14}$ Ibid. : 55-57.

15 Cf. Herbert Kitschelt, Zdenka Mansfeldova, Radoslaw Markowski, and Gabor Toka, Post-Communist Party Systems: Competition, Representation and Inter-Party Cooperation (New York: Cambridge University Press 1999).

${ }^{16}$ E.g. Oleh Protsyk, "Semi-Presidentialism under Post-Communism"; in: Robert Elgie, Sophia Moestrup, and Yu-Shan Wu, eds., Semi-Presidentialism and Democracy (New York: Palgrave 2011); Thomas Sedelius, The Tug-of-War between Presidents and Prime Ministers: Semi-Presidentialism in Central and Eastern Europe (Örebro: Örebro Studies in Political Science 2006).

${ }^{17}$ E.g. Robert Elgie and Sophia Moestrup, eds., Semi-Presidentialism Outside Europe (London: Routledge Press 2007).

18 Matthew S. Shugart and John M. Carey, supra note 4, p. 287.

${ }^{19}$ Fransesco Cavatorta and Robert Elgie, "The Impact of Semi-Presidentialism on Governance in the Palestinian Authority," Parliamentary Affairs 16:1 (2010); Thomas Sedelius and Joakim Ekman, "Intraexecutive Conflict and Cabinet Instability: Effects of Semi-Presidentialism in Central and Eastern Europe," Government and Opposition 45:4 (2010).
} 
dismissals are likely to lead to conflict over the regime itself. In Elgie's words "under president-parliamentarism the president and the legislature have an incentive to act against each other, which means there is little incentive to maintain the status quo and which in turn generates instability that is likely to undermine democratic performance and, in the worst-case scenario, lead to the collapse of democracy". ${ }^{20}$ And indeed, in several president-parliamentary countries in the former Soviet Union, e.g. Belarus, Russia and Uzbekistan, the strong presidential component, introduced from the very beginning, has contributed to legitimising and reinforcing already authoritarian tendencies. As such, the president-parliamentary system has provided a constitutionally sanctioned tool for accumulating power in the hands of presidents who have been less than interested in promoting democratic reforms. Instead of democratisation, the outcome has been increased power of already powerful presidents. A key factor favouring premierpresidentialism over president-parliamentarism is that the former provides the possibility of combining presidential leadership with a government anchored in parliament. Since the president cannot dismiss the government once it has been formed, he or she will have incentives to negotiate with the parliament in order to gain influence over the government and the political process. But again, the arguments presented above concerning the risk and consequences of intraexecutive conflict explain why there are few arguments in favour of premierpresidentialism over parliamentarism.

\section{UKRAINE AS A HYBRID REGIME}

Before we address the institutional tug of war in Ukraine in relation to semipresidentialism, we need to place the regime in its post-Soviet context. We consider Ukraine a hybrid regime moving along the continuum between democracy and authoritarianism. Levitsky \& Way use the term "electoral authoritarianism" for these regimes in which elections are the principal means for acquiring power but where "incumbents routinely abuse state resources, deny the opposition adequate media coverage, harass opposition candidates and their supporters, and in some cases manipulate electoral results". ${ }^{21}$ Hybrid regimes are inherently unstable and may eventually tilt either way - towards democracy or authoritarian rule. ${ }^{22}$ There is no linear progression towards democracy; and it is perfectly possible for a hybrid regime to "freeze" somewhere in-between democratic and authoritarian rule for a

\footnotetext{
${ }^{20}$ Oleh Protsyk, supra note 16: 35.

21 Steven Levitsky and Lucan A Way, "The Rise of Competitive Authoritarianism," Journal of Democracy 13:2 (2002): 53.

22 Larry Diamond, "Elections without democracy: Thinking about Hybrid Regimes," Journal of Democracy" 13: 2 (2002).
} 
long period of time. ${ }^{23}$ With the notable exception of Estonia, Latvia and Lithuania, this is a recurrent - and hardly surprising - pattern in former Soviet republics. ${ }^{24}$ They all became independent and committed themselves to competitive pluralism almost by default, when the Soviet Union disintegrated in 1990-91, but they did not have the backing of a vital civil society, a burgeoning tradition of the rule of law, or, for that matter, the benevolent support of the European Union like Estonia, Latvia, Lithuania and other East European enlargement countries. ${ }^{25}$ It was therefore relatively easy for the local political elites - most of whom had roots in the Soviet nomenklatura system - to halt or reverse the process of democratisation, once they had overcome the initial shock over the breakdown of the old world order.

Table 1: Freedom House average scores 1991-2011

\begin{tabular}{|c|c|c|c|c|c|c|c|c|c|}
\hline & 1991 & 1995 & 1999 & 2001 & 2003 & 2005 & 2007 & 2009 & 2011 \\
\hline Belarus & $\begin{array}{c}4 \\
(\mathrm{PF})\end{array}$ & $\begin{array}{c}5 \\
(\mathrm{PF})\end{array}$ & $\begin{array}{c}6 \\
(\mathrm{NF})\end{array}$ & $\begin{array}{c}6 \\
(\mathrm{NF})\end{array}$ & $\begin{array}{c}6 \\
(\mathrm{NF})\end{array}$ & $\begin{array}{c}6.5 \\
(\mathrm{NF})\end{array}$ & $\begin{array}{l}6.5 \\
(N F)\end{array}$ & $\begin{array}{c}6.5 \\
(\mathrm{NF})\end{array}$ & $\begin{array}{l}6.5 \\
(N F)\end{array}$ \\
\hline Georgia & $\begin{array}{l}5.5 \\
(N F)\end{array}$ & $\begin{array}{c}4.5 \\
(\mathrm{PF})\end{array}$ & $\begin{array}{c}3.5 \\
(\mathrm{PF})\end{array}$ & $\begin{array}{c}4 \\
(\mathrm{PF})\end{array}$ & $\begin{array}{c}4 \\
(\mathrm{PF})\end{array}$ & $\begin{array}{l}3.5 \\
(\mathrm{PF})\end{array}$ & $\begin{array}{c}3 \\
(\mathrm{PF})\end{array}$ & $\begin{array}{c}4 \\
(\mathrm{PF})\end{array}$ & $\begin{array}{l}3.5 \\
\text { (PF) }\end{array}$ \\
\hline Kyrgyz. & $\begin{array}{l}4.5 \\
(\mathrm{PF})\end{array}$ & $\begin{array}{c}4 \\
(\mathrm{PF})\end{array}$ & $\begin{array}{c}5 \\
(\mathrm{PF})\end{array}$ & $\begin{array}{c}5.5 \\
(\mathrm{NF})\end{array}$ & $\begin{array}{c}5.5 \\
(\mathrm{NF})\end{array}$ & $\begin{array}{l}5.5 \\
(\mathrm{NF})\end{array}$ & $\begin{array}{l}4.5 \\
(P F)\end{array}$ & $\begin{array}{l}4.5 \\
(\mathrm{PF})\end{array}$ & $\begin{array}{c}5 \\
(\mathrm{NF})\end{array}$ \\
\hline Moldova & $\begin{array}{l}4.5 \\
(P F)\end{array}$ & $\begin{array}{c}4 \\
(\mathrm{PF})\end{array}$ & $\begin{array}{c}3 \\
(\mathrm{PF})\end{array}$ & $\begin{array}{c}3 \\
(\mathrm{PF})\end{array}$ & $\begin{array}{l}3.5 \\
(\mathrm{PF})\end{array}$ & $\begin{array}{l}3.5 \\
(\mathrm{PF})\end{array}$ & $\begin{array}{l}3.5 \\
(P F)\end{array}$ & $\begin{array}{c}4 \\
(\mathrm{PF})\end{array}$ & $\begin{array}{c}3 \\
(\mathrm{PF})\end{array}$ \\
\hline Russia & $\begin{array}{c}3 \\
(\mathrm{PF})\end{array}$ & $\begin{array}{l}3.5 \\
(\mathrm{PF})\end{array}$ & $\begin{array}{l}4.5 \\
(\mathrm{PF})\end{array}$ & $\begin{array}{c}5 \\
(\mathrm{PF})\end{array}$ & $\begin{array}{c}5 \\
(\mathrm{PF})\end{array}$ & $\begin{array}{l}5.5 \\
(N F)\end{array}$ & $\begin{array}{l}5.5 \\
(N F)\end{array}$ & $\begin{array}{l}5.5 \\
(N F)\end{array}$ & $\begin{array}{l}5.5 \\
(\mathrm{NF})\end{array}$ \\
\hline Ukraine & $\begin{array}{c}3 \\
(\mathrm{PF})\end{array}$ & $\begin{array}{l}3.5 \\
(\mathrm{PF})\end{array}$ & $\begin{array}{l}3.5 \\
(\mathrm{PF})\end{array}$ & $\begin{array}{c}4 \\
(\mathrm{PF})\end{array}$ & $\begin{array}{c}4 \\
(\mathrm{PF})\end{array}$ & $\begin{array}{l}2.5 \\
(F)\end{array}$ & $\begin{array}{l}2.5 \\
(F)\end{array}$ & $\begin{array}{l}2.5 \\
(F)\end{array}$ & $\begin{array}{l}3.5 \\
\text { (PF) }\end{array}$ \\
\hline
\end{tabular}

Note: The average level of freedom as measured through Political Rights and Civil Liberties by Freedom House. Each country is ranked annually on a 1-7 scale, where $1=$ most free and

23 Joakim Ekman, "Political Participation and Regime Stability: A Framework of Analyzing Hybrid Regimes," International Political Science Review 30:1 (2009); Steven Levitsky and Lucan A. Way, Competitive Authoritarianism: Hybrid Regimes after the Cold War (New York: Cambridge University Press 2010).

24 Pranas Ciziunas, "Russia and the Baltic States: Is Russian Imperialism Dead?" Comparative Strategy 27 (2008); Lucan A. Way, "Authoritarian State Building and the Sources of Regime Competitiveness in the Fourth Wave: The Case of Belarus, Moldova, Russia, and Ukraine," World Politics 57 (2005).

25 Sten Berglund, Kjetil Duvold, Joakim Ekman, and Carsten Schymik, Where Does Europe End; Borders, Limits and Directions of the EU (Cheltenham: Edward Elgar 2009). 
$7=$ least free. The countries are classified into three categories labelled $\mathrm{F}=$ Free, PF $=$ Partly Free, or NF $=$ Not Free.

Source: Freedom House (2012), www.freedomhouse.org

A return to democratisation is by no means excluded, but it has not been the prevailing trend. Thus far, only three of the post-Soviet hybrid regimes - Georgia, Ukraine and Kyrgyzstan - have taken up the banner of democratisation. The turning point came in the form of mass protests against election fraud and repression known as the colour revolutions. Georgia's Rose Revolution of 2003 was the first one out in this chain of development, followed by Ukraine's Orange Revolution in 2004 and the Tulip Revolution in Kyrgyzstan in 2005. The latter may be dismissed as a failure, ${ }^{26}$ but the two former were comprehensive and resulted in change of regime directions. Ukraine has been somewhat ahead of Georgia, not only in terms of its Freedom House rating 2005-10 (cf. Table 1). It has also passed Samuel P. Huntington's famous "two-turnover test" ${ }^{27}$. Presidential power has changed hands twice since the Orange Revolution: from Kuchma to Yushchenko in 2005 and from Yushchenko to Yanukovych in 2010. ${ }^{28}$ Georgia will not have reached that far until President Mikheil Saakashvili has completed his current second term in office. $^{29}$ In addition, the Yushchenko era produced a climate where power and authority could be critically questioned in a variety of independent media. The political system that Yushchenko left to his successor in 2010 was still rather dysfunctional, but it was a political system where power and authority could be questioned and where the media had become highly pluralistic. ${ }^{30}$

The message of the new administration in Kyiv 2010 was one of business as usual and continuity rather than radical change. Yanukovych chose Brussels as his first foreign destination as president, thus reconfirming Ukraine's commitment to European integration. Membership is not on the agenda, but Ukraine is part of EU's European Neighbourhood Policy (ENP) and thus qualifies for just about everything the EU has to offer its neighbours but common institutions. ${ }^{31}$ Yanukovych's subsequent trip to Moscow did spell change, but not radical change. It rather served to normalise relations between Ukraine and Russia. The deal he worked out

26 The Tulip revolution actually produced more of the same repression and electoral fraud that had brought the new regime to power; and in April 2010 its leader, President Kurmanbek Bakiyev, was forced to flee the country in the midst of a political upheaval.

27 Samuel P. Huntington, The Third Wave: Democratization in the Late Twentieth Century (Norman: University of Oklahoma Press 1991).

${ }^{28}$ Henry Hale, "The Uses of Divided Power," Journal of Democracy 21:3 (2010).

${ }^{29}$ President Saakashvili was re-elected for a second term in January 2008. The term is five years and the same person may be elected president only for two consecutive terms (Constitution of Georgia, Chapter 4, Article 70).

30 Nathaniel Copsey and Natalia Shapovalova, "The Ukrainian Presidential Election of 2010," Representation 46:2 (2010).

31 Ruben Zaiotti, "Of Friends and Fences: Europe's Neighbourhood Policy and the 'Gated Community Syndrome'," European Integration 29:2 (2007); Sten Berglund et al., supra note 25. 
with the Russian leaders - to extend the lease on the Russian naval base in Sevastopol in exchange for Russian gas at favourable prices - was met with severe criticism from the opposition. The extension until 2047 was considered far too generous. The decision making process lacked transparency; and the decision violated nationalist sentiments and possibly the Ukrainian constitution. From a geopolitical perspective, however, the decision made good sense. It removed two contentious issues from the Ukrainian-Russian agenda and it gave the battered Ukrainian economy a badly needed boost in the form of steady gas supply at affordable prices. The two state visits in a sense symbolize Ukraine's political predicament. The country is literally torn between East and West between Moscow and Brussels. Yanukovych - and his Party of Regions - draws the bulk of his support from the eastern part of the country and harbours matching geopolitical preferences. Yushchenko, Tymoshenko and the other architects of the Orange Revolution have their strongholds in Kyiv and in the western part of the country and generally lean towards the West.

The pending trial of former President Leonid Kuchma (1994-2005) for his alleged involvement in the murder of investigative journalist and dissident Georgiy Gongadze was interpreted as yet another sign of normalcy until the charges were dropped in May 2011. ${ }^{32}$ The criminal investigation had been running for more than a decade without leading to a trial until the case was reopened by the Yanukovych regime in March 2011. Yanukovych referred to the drawn out criminal investigation as a procedure that "must be completed". ${ }^{33}$ This was the rhetoric of a statesman speaking from a solid platform of the rule of law, and it was all the more impressive considering that Yanukovych is a former protégé of Leonid Kuchma. The problem is just that the rule of law does not prevail in Ukraine. The judiciary and the executive have always been too closely intertwined. The Kuchma trial could have been an important step towards judicial independence, but the legal proceedings against and subsequent incarceration of former Prime Minister Yulia Tymoshenko on corruption charges tell another story - the all too familiar story of a Ukrainian president using the penal code to emasculate the opposition. In 2011, more than thirty criminal investigations were running against members of the opposition. Meanwhile, there was only one investigation underway concerning a member of the Party of Regions. ${ }^{34}$

\footnotetext{
${ }^{32}$ Roman Olearchyk, "Kuchma No longer Suspect in Murder Trial," Financial Times (May 27, 2011).

${ }^{33}$ Gina S. Lentine, "Kyiv's Whodunnit: Leonid Kuchma's 'Long-Delayed' Murder Trial," Center for Strategic and International Studies (CSIS), Washington D.C. (2011) // www.csis.org (accessed June 2, 2011).

${ }^{34}$ Valery Kalnysh, "Yulia Tymoshenko: Guilty or Persecuted?" EaPCommunity (2011) // www.easternpartnership.org (accessed May 17, 2011).
} 
The local elections on 31 October 2010 may be dismissed in similar terms. Ukrainian authorities did issue invitations to international organisations to monitor the elections but too late for an OSCE mission or other large observer groups to be sent to Ukraine. ${ }^{35}$ The only systematic, long-term and large-scale observation conducted was that of the US-funded Ukrainian civil network OPORA. Its reports strongly suggest that the elections were neither free, nor fair - an impression corroborated by short-term observation missions present on the day of the election, independent journalists and numerous official complaints launched by the opposition. The deviations from standard democratic electoral practices were in fact so numerous and so fundamental that the October elections could serve as a manual for how to steal a supposedly democratic election. The rules of the game were changed on short notice. One half of the deputies were to be elected by proportional representation, the other half by plurality vote in single-member districts. The ruling majority first simply adjourned the regular date for the elections and then arbitrarily scheduled the elections for October 31 . The opposition was not only systematically underrepresented in the local electoral commissions. It was frequently the target of electoral commissions acting in collusion with the government. Yulia Tymoshenko was thus prevented from running in traditional strongholds such as Kyiv and Lviv. Opora and other observers documented a long list of irregularities on Election Day. Ballots cast were occasionally removed from the polling station; voters were "assisted" within polling booths; hospital and medical institutions voted unanimously for certain candidates; ballots were photographed; voters were openly bribed; and electoral observers were denied access to polling stations. ${ }^{36}$ The opposition was in disarray after the recent presidential elections and would have had to fight an uphill battle even in a free and fair election, but Yanukovych obviously was not prepared to take any chances. The international repercussions - lower freedom ratings by Freedom House and open criticism by the international community - were easy to foresee, but they apparently carried less weight on the recently elected president than the prospect of a fool-proof grip on power. If this is the model to be applied in the upcoming parliamentary elections scheduled for the autumn of 2012, it will deliver yet another piece of evidence in favour of the notion that the current presidential administration in Kyiv is guided by a rollback strategy. The Ukrainian hybrid regime is still moving - not towards democracy but rather towards an authoritarian stalemate such as existed prior to the Orange Revolution.

35 Nico Lange, "Local Elections in Ukraine: Yanokovych's Consolidation of Power," Country Report, Konrad Adenauer Stiftung (2010) // www.kas.de/ukraine (accessed May 17, 2011).

${ }^{36}$ Ibid. 
In the subsequent empirical sections, we will outline some general aspects of the constitutional tug of war in relation to the semi-presidential structure - first during the Kuchma era, under the 1996 president-parliamentary constitution (2005), and then during the post-Orange Yushchenko period under the premierpresidential system 2006-10.

\section{PRESIdENTIAL PRIMACY AND CONSTItUTIONAL STRUggles IN} THE KUCHMA ERA

Despite Ukraine's delayed adoption of a new constitution, Katarina Wolczuk asserts that "the final choices were made in a haphazard and improvised manner". ${ }^{37}$ Overall, Kuchma and his administration had the upper hand and were the driving force in the constitutional process, guided by defined institutional interests and bolstered by considerable institutional resources. But, as opposed to his colleagues in Belarus and most other post-Soviet states, the president of Ukraine did not get it all his way. Instead Kuchma's ten years as president (19942004) were marked by a struggle, both between the president and the prime ministers, and between the president and the parliament. Repeated constitutional proposals by Kuchma in the 1990s, envisioning the creation of a pure presidential republic, were turned down by the parliament, as were his proposals designed to give the president the right to dissolve the parliament.

In accordance with the president-parliamentary system, the structure of the Ukrainian 1996 constitution allowed the president to distance himself politically from the economic and social policies of the government, while giving him the right to dismiss government members whenever he saw fit. Just like President Yeltsin of Russia, Kuchma 'hid' behind his prime ministers in order to avoid popular dissatisfaction with the ineffective economic reforms. He even undermined or altered government initiatives in economic and fiscal policy to maintain his own public legitimacy and political relevance. He took advantage of his dominance over - and at the same time separation from - the government and broadly defined goals, strategies and targets. Up until 2004, Kuchma went through no less than seven prime ministers. He was persistent and careful about securing his position as the dominant figure within the executive. According to observers, he outmanoeuvred two potential threats to his second term in office in the mid 1990s by dismissing both Yevhen Marchuk and later Pavel Lazarenko ${ }^{38}$ from the post as

\footnotetext{
37 Kataryna Wolczuk, "Ukraine: Tormented Constitution-Making": 244; in: Jan Zielonka, ed., Democratic Consolidation in Eastern Europe: Volume 1. Institutional Engineering (Oxford: Oxford University Press 2001).

38 Lazarenko was initially recruited to top-level positions by Kuchma and was part of the so-called "Dnipropetrovsk-clan" from Kuchma's home base. In June 2004, Lazarenko was convicted of fraud,
} 
prime minister, in order to prevent them from growing too powerful and becoming his rivals for the presidency. ${ }^{39}$

Corruption accelerated under the Kuchma era with a number of locally based oligarchic conglomerates buying state enterprises at bargain prices in the name of privatisation. In general, the so-called oligarchs were able to operate their businesses without fear of independent control. But in 2000, Kuchma's power began to weaken as the wealth of the oligarchs grew significantly and Kuchma's personal involvement in corruption and criminality started coming to light, and by early 2001, the so-called Gongadze scandal was revealed. Release of recordings allegedly from Kuchma's office implicated the president in the death of journalist and dissident, Georgy Gongadze. These revelations sparked anti-Kuchma protests on several occasions throughout the country and opened things up for a significant opposition movement. However, by blocking efforts to initiate the legal procedure needed to formally make charges, Kuchma managed at the time to stall the campaign against him. In addition, Kuchma's oligarchic networks were far from pleased with the increasingly independent prime minister at the time, Viktor Yushchenko, who had gained a reputation of integrity. Consequently, after only eighteen months as prime minister, Yushchenko was dismissed by Kuchma in May 2001. Although Kuchma and his supporters were rid of Yushchenko for the time being, their actions had transformed him from a technocrat into an opposition leader with a strong public base. In 2002, Kuchma began to realise that Yushchenko might win the upcoming presidential elections scheduled for 2004. In a somewhat ironical twist, Kuchma reversed his earlier position as a proponent of a pure presidential system and proposed a strengthening of the position of the prime minister to the detriment of the presidency. Although the proposal was unacceptable to Yushchenko and even to Yanukovych (Kuchma's preferred choice as successor), Kuchma managed to persuade the pro-presidential parties in parliament to prepare the constitutional amendment. On April 8, 2004, the proposal failed to gain the necessary support of two-thirds of the deputies in parliament. ${ }^{40}$ Eight months later a similar amendment was to be signed into law by the main actors of the Orange Revolution.

Imposing constitutional change as a way of managing conflict is undoubtedly a high risk strategy in terms of political stability and system legitimacy. The persistent constitutional struggle under Kuchma is illustrative. It resulted in

conspiracy to launder money and transportation of stolen property by a US District Court. He was accused of having stolen from the state and extorted hundreds of millions of dollars from businesses between 1995 and 1997, when he served first as deputy prime minister and then as prime minister.

${ }^{39}$ Adrian Karatnycky, "Ukraine's Orange Revolution," Foreign Affairs 84:2 (2005).

${ }^{40}$ Kimitaka Matsuzato, "Disintegrated Semi-Presidentialism and Parliamentary Oligarchy in Post-Orange Ukraine": 197-198; in: Robert Elgie, Sophia Moestrup and Yu-Shan Wu, eds., Semi-Presidentialism and Democracy (Basingstoke: Palgrave Macmillan, 2011). 
polarisation between the executive and legislative branches, in widespread popular cynicism, and in stalemate even in policy areas not directly related to the constitutional issue. As if this were not enough, constitutional strife diverted attention from other policy areas and relegated them to a secondary position. The recurrent constitutional clashes in Ukraine stalled effective policy work for several years. ${ }^{41}$

The dangers associated with undermining the legitimacy of the existing constitutional order are readily apparent in fledgling democracies like Ukraine under Kuchma. A president rejecting parliamentary solutions in favour of strong presidential rule in a context marked by a weak civil society, a party system in flux, widespread popular distrust in political elites, and little or no respect for the rule of law, may render the ultimate blow to democratisation. ${ }^{42}$ Yet, Ukraine did not slide into the kind of presidential authoritarianism that was gradually built into the constitution in Belarus and several of the Central Asian republics. This fortunate outcome can be attributed to an unintended series of "checks and balances", resulting from a number of political cleavages that cut across institutions and political grouping. ${ }^{43}$

Ukraine did indeed experience the typical pitfall of the president-parliamenary system as the prime ministers in several cases were pulled in different directions by contradictory orders from the president and parliament. Kuchma, just like e.g. Boris Yeltsin in Russia, effectively used the prime ministers as shields against popular dissatisfaction and critique. By blaming the prime ministers for failed reforms and economic recession, Kuchma attempted to escape public disenchantment while at the same time demonstrating action and responsibility. To what extent these tactics were successful can of course be debated, but the fact is that Kuchma (and Yeltsin) managed to get re-elected and keep hold on the presidency for about ten years. These factors illustrate how the president can effectively use his stronger position vis-à-vis the prime minister under a president-parliamentary arrangement. The prime ministers are in a more disadvantageous position and tend to be squeezed between the president and the parliament. The efforts by the parliament and the president to control the cabinet serve as a built-in incitement for executivelegislative conflict. However, a president-parliament divide can also be exploited and utilised by the cabinet to create a favourable position in negotiations. By the same logic the cabinet became a power centre in its own right, and could often play on the uncertainty in general, and on the divide between the president and the

\footnotetext{
${ }^{41}$ Kataryna Wolczuk, The Moulding of Ukraine: The Constitutional Politics of State Formation (Budapest: Central European University Press 2001).

42 Oleh Protsyk, "Politics of Intra-Executive Conflict in Semi-Presidential Regimes in Eastern Europe," East European Politics and Society 18:2 (2005).

${ }^{43}$ Kataryna Wolczuk, supra note 41 ; Sara Birch, supra note 3.
} 
parliament in particular ${ }^{44}$. Needless to say, this conflictive institutional triangle between the president, prime minister and parliament rendered effective policy making very difficult under the Kuchma era.

\section{PREMIER-PRESIDENTIAL CONFLICTS AND THE DEMOCRATIC REGIME DIRECTION 2004-10}

The legacy of Kuchma's regime continued to cast its shadow on the postOrange period. Not only did the complex system of corrupt patronage remain largely intact; the institutional tug of war was also carried over into the Yushchenko era and even intensified. The institutional rivalry and the inability to deal with necessary reforms had a detrimental effect on the regime as it caused widespread disillusionment within society at large. The lack of a constitutional mechanism for regulating the division of labour between the president and the prime minister resulted in recurrent political crises. ${ }^{45}$

As compensation for accepting repeated presidential elections under "fairer conditions" in December 2004, pro-Kuchma deputies in parliament requested the realisation of the constitutional amendment proposed by Kuchma some eight months earlier. Yushchenko was still against the amendment but leaders of his party, Our Ukraine, persuaded him to accept it. So, parliament adopted the amendment and Kuchma, Yanukovych and Yushchenko signed it into law. With the constitutional amendments in force from early 2006, the president lost the power to appoint the prime minister, and was instead called upon to present a candidate for this office to be confirmed by the parliament. ${ }^{46}$ Even more crucial, the president lost the power to dismiss the prime minister. ${ }^{47}$ On the other hand, the amendments opened up new possibilities for the president to dissolve the parliament. If the plenary meeting of the parliament does not start working within thirty days after the beginning of the regular session and if the parliament is unable to form a majority coalition with more than 226 out of 450 deputies, the president is entitled to dissolve parliament. ${ }^{48}$ At the same time, the powers of the prime minister remained relatively stable. The prime minister retained the right to appoint candidates for the cabinet, though the authority to approve them shifted from the president to the parliament. ${ }^{49}$ It is clear that the underlying motives were to move power from the executive (president and prime minister) to the legislative

${ }^{44}$ Charles R. Wise and Volodomyr Pigenko, "The Separation of Powers Puzzle in Ukraine"; in: Taras Kuzio et al., eds., State and Institution Building in Ukraine (New York: St. Martin's Press, 1999).

${ }^{45}$ Kimitaka Matsuzato, supra note 40.

${ }^{46}$ Amendments to the Constitution of Ukraine, adopted 8 December 2004, CDL (2005) 036 (Strasbourg: Council of Europe), Article 114.

47 Ibid., Article 87.

${ }^{48}$ Ibid., Article 90.

${ }^{49}$ Ibid., Article 114. 
(parliament) branch, thus creating a premier-presidential system where power was more evenly balanced both within the executive and between the executive and the legislative branches. ${ }^{50}$

As Yushchenko reluctantly accepted the decision to curtail the prerogatives of the president after 2005, he hoped that a one-year window of a strong presidency would give him enough time to build a firm platform of parliamentary support. Before the constitutional amendments went into force, Yushchenko used his soonto-expire authority to dismiss the prime minister, and sacked Yulia Tymoshenko and her government. Yushchenko cited internal corruption allegations as the main reason for the dismissal, but apparently there was also an intra-executive conflict behind it. Yushchenko accused Tymoshenko of abusing her position, and described the decision to dismiss her and her cabinet as a "matter of honour". ${ }^{51}$ Tymoshenko, on her end, countered that Yushchenko feared her popularity and added that she would stand against him in future elections. The president's team, she said, "has merely swapped one bunch of corrupt tycoons for another". ${ }^{52}$ Yushchenko countered with more corruption charges.

The president apparently had little leverage within the political system and even within his own party. The intra-executive struggles paved the way for Yanukovych, whose Party of Regions made a strong comeback already in the parliamentary elections of 2006. Following the formation of Yanukovych's cabinet, conflicts soon occurred regarding the "presidential ministries" of interior and foreign affairs. Under the new premier-presidential system "the anti-crisis parliamentary coalition" led by the Party of Region, dismissed the ministers of foreign and interior affairs in December 2006. The most salient clash concerned Yushchenko's foreign minister, Borys Tarasiuk, as his policy approach towards deeper Euro-Atlantic integration and a condemning of the Russian Black Sea Fleet in Crimea, ran counter to the policy direction of Prime Minister Yanukovych's more Moscow-friendly orientation. A decree issued by Yushchenko together with a local court's decision formally reinstated Tarasiuk as foreign minister. Yanukovych's government, however, refused to recognise this and in January 2007, Tarasiuk announced his resignation. This was a logical outcome of the premier-presidential system (200610) where cabinet ministers were unilaterally subjected to parliamentary confidence for their survival in office.

Yanukovych used his increased strength to challenge the president by introducing new laws designed to give the prime minister complete control over the

\footnotetext{
50 Thomas O’Brien, "Problems of Political Transition in Ukraine: Leadership Failure and Democratic Consolidation," Contemporary Politics 16:4 (2010).

51 Robert Parsons, "Ukraine: Yushchenko Accuses Former Prime Minister of Misuse of Power," RFE/RL Report (September 14, 2005) // www.rferl.org (accessed September 15, 2005).

52 Ibid.
} 
cabinet, further weakening the influence of the president. Yushchenko responded by dissolving the parliament as it was unable to form a sufficient majority. New elections were called and set for September 2007 providing a new opportunity for the Orange coalition to regain power. After a new round of nearly three months of coalition negotiations, Tymoshenko again returned as prime minister. This arrangement resulted in a series of new intra-executive struggles between President Yushchenko and Prime Minister Tymoshenko and a definitive breakup of the Orange coalition between the Bloc Yulia Tymoshenko (BYUT) and Yushchenko's party Our Ukraine. Since the president was now constitutionally stripped of the authority to dismiss the prime minister, Tymoshenko was, however, able to stay in office until the presidential elections of $2010 .^{53}$

The new institutional balance made it impossible for any of the key actors to monopolise executive authority. So the intra-executive rivalry went on. In two recent studies by Sedelius and Ekman ${ }^{54}$, and Sedelius and Mashtaler ${ }^{55}$ the level of intra-executive conflict was measured in a number of post-communist countries with semi-presidential constitutions. The estimates for Ukraine are reported in Table 3. They testify to a high level of conflict between the president and the prime minister in all cabinets under Yushchenko. The frequent occurrence of conflict also under Kuchma suggests that regardless of semi-presidential form Ukraine has a long-lasting tradition of intra-executive conflict.

Table 2: Intra-executive conflict between president and prime minister 1991-2011

\begin{tabular}{|c|c|c|}
\hline President & Prime Minister & $\begin{array}{l}\text { Intra-executive } \\
\text { conflict }\end{array}$ \\
\hline L Kravchuk (Dec 91- July 94) & L Kuchma (Oct 92-Sep 93) & High \\
\hline $\begin{array}{l}\text { L Kuchma (July 94-Oct 99) } \\
\text { - " - } \\
-" \text { - } \\
\text { - " - }\end{array}$ & $\begin{array}{l}\text { V Masol (June 94-Mar 95) } \\
\text { Y Marchuk (Mar 95-May 96) } \\
\text { P Lazarenko (May 96-July 97) } \\
\text { V Pustovochenko (July 97-Dec 99) }\end{array}$ & $\begin{array}{l}\text { Low } \\
\text { High } \\
\text { High } \\
\text { Low }\end{array}$ \\
\hline $\begin{array}{l}\text { L Kuchma (Nov 99-Oct 04) } \\
-" \text { - } \\
-" \text { - }\end{array}$ & $\begin{array}{l}\text { V Yushchenko (Dec 99-May 01) } \\
\text { A Kinakh (May 01-Nov 02) } \\
\text { V Yanukovych (Nov 02- Jan 05) }\end{array}$ & $\begin{array}{l}\text { High } \\
\text { Low } \\
\text { Low }\end{array}$ \\
\hline $\begin{array}{l}\text { V Yushchenko (Jan 05-Feb 10) } \\
\text { - "- } \\
\text { - " - }\end{array}$ & $\begin{array}{l}\text { Y Tymoshenko (Jan 05-Sep 05) } \\
\text { V Yanukovych (Aug 06-Dec 07) } \\
\text { Y Tymoshenko (Dec 07-Mar 10) }\end{array}$ & $\begin{array}{l}\text { High } \\
\text { High } \\
\text { Medium-High }\end{array}$ \\
\hline V Yanukovych (Feb 10- ) & M Azarov (Mar 10- ) & Low \\
\hline
\end{tabular}

\footnotetext{
53 Thomas O'Brien, supra note 50.

${ }^{54}$ Thomas Sedelius and Joakim Ekman, supra note 19.

55 Thomas Sedelius and Olga Mashtaler, "A Troubled Tandem? Character and Issues of Intra-Executive Conflict under Semi-Presidentialism," Paper presented at the International Political Science Association's (IPSA) World Congress in Madrid (July 8-12, 2012).
} 
Note: Sedelius and Ekman define intra-executive conflict as where "there has been an observable clash between the president and the prime minister and/or between the president and other government ministers, manifested through obstructive or antagonistic behaviour from either side, directed towards the other. ${ }^{156}$ Conflicts are coded on an ordinal scale: low, medium and high conflict. When no significant conflict between the president and the cabinet has been reported, the relationship has been considered as non-conflictive and hence the conflict-level estimated as low. Under periods of episodic but manifest and observable conflict, the level has been estimated as medium. Finally, instances of durable and severe tension between the president and the cabinet have been estimated as high levels of conflict. Source: Sedelius and Mashtaler (2012).

The reasons why Yushchenko failed to turn his popularity from the Orange revolution into effective political leadership are manifold, but some of them are directly related to the institutional framework of premier-presidentialism. For premier-presidentialism to be effective, there are two principal paths to follow: either the president chooses a rather symbolic role leaving the leadership of the executive to the prime minister - as is gradually about to occur in e.g. Bulgaria and has long been standard procedure in e.g. Iceland and Austria - or the president becomes the (informal) leader of the government and attempts to command a parliamentary majority along the lines of the French model. The latter alternative implies that the president identifies with a party, works for the success of this party and - if need be - sets out to build a coalition in the legislature ready to support his choice of prime minister. The highly personal nature of rivalry in Ukrainian politics often based on fear that the counterpart might become a presidential contender has prevented consolidation of parliamentary majorities gravitating toward a common programmatic spectrum. In order to satisfy their own ambitions, Yushchenko, Tymoshenko and Yanukovych have at different times employed a divide-and-rule tactic. Yushchenko's weakness was a lack of leverage on the parliamentary coalition in which Tymoshenko's party was the dominant partner. Unable to rely on party support, President Yushchenko had to rely on his constitutional powers and on the presidential office itself. ${ }^{57}$ Hence, with the key actors using considerable institutional leverage to obstruct durable inter-party collaboration, one can indeed argue that the premier-presidential arrangement contributed to ineffective government and, in the longer run, regime instability. Nonetheless and despite all these problems, the hybrid regime steered in a generally democratic direction throughout the Yushchenko era. ${ }^{58}$

\footnotetext{
56 Thomas Sedelius and Joakim Ekman, supra note 19: 513.

57 Thomas O'Brien, supra note 50: 363.

${ }^{58}$ Cf. Henry Hale, supra note 28.
} 
The return to the president-parliamentary constitution of 1996 strongly suggests that Yanukovych is guided by a rollback strategy. Power sharing served Yanukovych quite well in his capacity as party leader and sometime prime minister under Yushchenko, but it became much more of a nuisance in his capacity as president - hence the return to the constitution of 1996 . Where one stands on constitutional issues clearly depends on where one is located in the Ukrainian political hierarchy. Yanukovych has thus far been much more successful than his predecessor in his attempts at building a strong presidency. He owes his success not only to constitutional engineering but also to the absence of a strong and united opposition. In a context of relative party system weakness, where politics often takes the form of power struggles between a small number of top politicians rather than a competition among policy programmes, Yanukovych' current position seems to be strong. In fact there is a kind of normative consensus in favour of a stronger presidency in Ukraine. This is one thing that Tymoshenko, Yushchenko and Yanukovych have all argued for at different times. And the stronger president norm is certainly present among a large majority of the Ukrainians. ${ }^{59}$

It may very well be that the structural constraints on Ukrainian politics make consolidation of power difficult, perhaps impossible in a short-time perspective. The country is regionally divided; the state and its institutions are weak and Ukrainian politics is not driven by ideology. ${ }^{60}$ Time may also have run out for some of the policy changes likely to be contemplated by a regime bent on turning the clock backwards to the way things were before the Orange Revolution. But the record of other post-Soviet states with president-parliamentary systems hardly points in the direction of democracy.

\section{CONCLUDING REMARKS}

While many factors have affected the altering of regime directions in Ukraine, the design of executive-legislative relations is a most salient one. We asked at the outset of this article, to what extent and in what ways conventional arguments against semi-presidentialism are relevant for understanding the shifting directions of the Ukrainian regime. In the literature, we initially identified two general warnings against semi-presidentialism. First, and most frequently cited, two parallel executives (president and prime minister) acting on separate electoral mandates create a built-in trigger of conflicts, which may have destabilising effects on the political system. Second, none of the two sub-types of semi-presidentialism are

\footnotetext{
59 Paul D'Anieri, "Structural Constraints in Ukrainian Politics," East European Politics \& Societies 25:28 (2011).

60 Ibid.
} 
strongly promoted in the literature, but there is almost consensus that presidentparliamentary systems are inferior to premier-presidentialism with respect to policy effectiveness and democratisation.

Our analysis of Ukraine largely supports these arguments. First, the continuous conflicts between the president, prime minister and parliament under both types of semi-presidentialism have been damaging to institutionalisation and political stability in Ukraine. And these conflicts are strongly related to the dual executive structure of semi-presidentialism. In the era of Kuchma, the prime ministers were often used as shields against popular dissatisfaction and critique. By blaming the prime ministers for failed reforms and economic recession, Kuchma attempted to escape public disenchantment while at the same time demonstrating action and responsibility. In addition, the executive-legislative tensions between Kuchma and the parliament often resulted in intra-executive conflicts between the president and cabinet. Quite similar to the case of Russia under President Yeltsin, the prime ministers were in several cases pulled in different directions by contradictory orders from the president and parliament. Since the presidentparliamentary system allowed Kuchma to unilaterally dismiss the prime minister at any time, cabinet instability rather than effective reforms characterised much of his presidency.

The premier-presidential regime, literally forced upon Yushchenko in 2006, had some of the same problems as the previous president-parliamentary system. The institutional rivalry was still there, the domains of power within the executive were still vague, and the level of intra-executive conflict remained high. Yushchenko never adjusted to the constitutional reform. He never gave up the ambition to dominate the executive, but failed to build a sufficiently durable parliamentary platform along the lines of the French model. The personal rivalry between Yushchenko, Tymoshenko and Yanukovych prevented any durable parliamentary majorities. Unable to rely on party support, President Yushchenko had to rely on his constitutional powers and on the presidential office itself. Hence, with the key actors using considerable institutional leverage to obstruct inter-party collaboration, one can indeed argue that the premier-presidential arrangement contributed to ineffective government.

But still, and related to the second argument, premier-presidentialism in Ukraine had two main advantages over president-parliamentarism. It weakened the presidential dominance and it explicitly anchored the survival of the government in parliament. Following Linz's oft-cited arguments against presidentialism, pure parliamentarism would arguably have been preferable, as it considerably reduces 
the potential for intra-executive conflict; nevertheless, for a hybrid regime like Ukraine premier-presidentialism is definitely a step in the right direction.

There is no consensus about the rules of the game in Ukrainian politics. The constitution and the electoral law have been subject to recurrent modifications, changing the thrust of the entire political system. The underlying motives are clearly instrumental. Where you sit in the Ukrainian political hierarchy determines where you stand on constitutional reform. Presidents want a strong presidency and prime ministers a stronger parliament; but once catapulted into the presidency, a former prime minister may very well change his constitutional priorities. In this respect, the two semi-presidential arrangements in Ukraine since 1996 have had a negative impact by exacerbating rather than mitigating inter-institutional rivalry. As Sarah Birch argues, constitutional reforms have "tended to follow rather than govern the de facto balance of power". ${ }^{61}$ The high stakes of the elections - as demonstrated by the presidential elections of 2004 and 2010 as well as by the allegedly fraudulent local elections of 2011 - are in fact typical of hybrid regimes. Rather than simply being contests to determine who is to govern, elections are still events with the potential of altering the whole constitutional structure. Tampering with the rules rather than playing by the rules still seems to be the rule in Ukrainian politics.

The post-communist countries with the strongest presidencies do after all have the most dismal records in terms of democratisation. The return to presidentparliamentary rule in the wake of the presidential elections of 2010 represents a step in the wrong direction for Ukraine - not towards but away from democracy.

\section{BIBLIOGRAPHY}

1. Amendments to the Constitution of Ukraine. Adopted December 8, 2004, CDL 2005: 036. Strasbourg: Council of Europe, 2005.

2. Berglund, Sten, Kjetil Duvold, Joakim Ekman, and Carsten Schymik. Where Does Europe End; Borders, Limits and Directions of the EU. Cheltenham: Edward Elgar, 2009.

3. Birch, Sara. "Semi-Presidentialism in Ukraine": 219-238. In: Robert Elgie \& Sophia Moestrup, eds. Semi-Presidentialism in Central and Eastern Europe. Manchester: Manchester University Press, 2008.

4. Cavatorta, Fransesco, and Robert Elgie. "The Impact of Semi-Presidentialism on Governance in the Palestinian Authority." Parliamentary Affairs Vol. 16, No. 1 (2010): 22-40.

\footnotetext{
${ }^{61}$ Sara Birch, supra note 3: 236.
} 
5. Ciziunas, Pranas. "Russia and the Baltic States: Is Russian Imperialism Dead?" Comparative Strategy Vol. 27 (2008): 287-307.

6. Constitution of Georgia. Adopted on August 24, 1995, and Last Amended on December 27, 2006 // www.parliament.ge (accessed June 2, 2011).

7. Copsey, Nathaniel, and Natalia Shapovalova. "The Ukrainian Presidential Election of 2010." Representation Vol. 46, No. 2 (2010): 211-225.

8. D'Anieri, Paul. "Structural Constraints in Ukrainian Politics." East European Politics \& Societies Vol. 25, No. 28 (2011): 28-46.

9. Diamond, Larry. "Elections without Democracy: Thinking about Hybrid Regimes." Journal of Democracy Vol. 13, No. 2 (2002): 21-35.

10. Duverger, Maurice. "A New Political System Model: Semi-presidential Government." European Journal of Political Research Vol. 8 (1980): 165-187.

11. Ekman, Joakim. "Political Participation and Regime Stability: A Framework of Analyzing Hybrid Regimes." International Political Science Review Vol. 30, No. 1 (2009): 7-31.

12. Elgie, Robert, and Sophia Moestrup, eds. Semi-Presidentialism in Central and Eastern Europe. Manchester: Manchester University Press, 2008.

13. Elgie, Robert, and Sophia Moestrup, eds. Semi-Presidentialism Outside Europe. London: Routledge Press, 2007.

14. Elgie, Robert. "Duverger, Semi-Presidentialism and the Supposed French Archetype." West European Politics Vol. 32, No. 2 (2009): 248-267.

15. Elgie, Robert. Semi-Presidentialism: Sub-Types and Democratic Performance. Oxford: Oxford University Press, 2011.

16. Elgie, Robert, Sophia Moestrup, and Yu-Shan Wu, eds. Semi-Presidentialism and Democracy. Basingstoke: Palgrave Macmillan, 2011.

17. Elgie, Robert. "The Classification of Democratic Regime Types: Conceptual Ambiguity and Contestable Assumptions." European Journal of Political Research Vol. 33, No. 2 (1998): 219-238.

18. Freedom House. Freedom in the World 2012 // www.freedomhouse.org (accessed February 17, 2012).

19. Hale, Henry. "The Uses of Divided Power." Journal of Democracy Vol. 21, No. 3 (2010): 84-98.

20. Huntington, Samuel P. The Third Wave: Democratization in the Late Twentieth Century. Norman: University of Oklahoma Press, 1991.

21. Kalnysh, Valery. "Yulia Tymoshenko: Guilty or Persecuted?" EaPCommunity (2011) // www.easternpartnership.org (accessed May 17, 2011).

22. Karatnycky, Adrian. "Ukraine's Orange Revolution." Foreign Affairs Vol. 84, No. 2 (2005): 35-52. 
23. Kitschelt, Herbert, Zdenka Mansfeldova, Radoslaw Markowski, and Gabor Toka. Post-Communist Party Systems: Competition, Representation and InterParty Cooperation. Cambridge and New York: Cambridge University Press, 1999.

24. Lange, Nico. "Local Elections in Ukraine: Yanukovych's Consolidation of Power." Country Report, Konrad Adenauer Stiftung (2010) // www.kas.de/ukraine (accessed May 17, 2011).

25. Lentine, Gina S. "Kyiv's Whodunnit: Leonid Kuchma's 'Long-Delayed' Murder Trial." Center for Strategic and International Studies (CSIS), Washington D.C. (2011) // www.csis.org (accessed June 2, 2011).

26. Levitsky, Steven, and Lucan A. Way. Competitive Authoritarianism: Hybrid Regimes after the Cold War. New York: Cambridge University Press, 2010.

27. Levitsky, Steven, and Lucan A Way. "The Rise of Competitive Authoritarianism." Journal of Democracy Vol. 13, No. 2 (2002): 51-65.

28. Linz, Juan J. "The Perils of Presidentialism." Journal of Democracy Vol. 1 (1990): 51-69.

29. Linz, Juan J. "Presidential or Parliamentary Democracy: Does it Make a Difference": 3-87. In: Juan J. Linz and Arturo Valenzuela, eds. The Failure of Presidential Democracy: Comparative Perspectives. Baltimore: Johns Hopkins University Press, 1994.

30. Matsuzato, Kimitaka. "Disintegrated Semi-Presidentialism and Parliamentary Oligarchy in Post-Orange Ukraine": 192-209. In: Robert Elgie, Sophia Moestrup and Yu-Shan Wu, eds. Semi-Presidentialism and Democracy. Basingstoke: Palgrave Macmillan, 2011.

31. O'Brien, Thomas. "Problems of Political Transition in Ukraine: Leadership Failure and Democratic Consolidation." Contemporary Politics Vol. 16, No. 4 (2010): 355-367.

32. Olearchyk, Roman. "Kuchma No longer Suspect in Murder Trial." Financial Times (May 27, 2011).

33. Parsons, Robert. "Ukraine: Yushchenko Accuses Former Prime Minister of Misuse of Power." RFE/RL Report (September 14, 2005) // www.rferl.org (accessed September 15, 2005).

34. Protsyk, Oleh. "Semi-Presidentialism under Post-Communism": 98-116. In: Robert Elgie, Sophia Moestrup, and Yu-Shan Wu, eds. Semi-Presidentialism and Democracy. New York: Palgrave, 2011.

35. Protsyk, Oleh. "Politics of Intra-Executive Conflict in Semi-Presidential Regimes in Eastern Europe." East European Politics and Society Vol. 18, No. 2 (2005): 1-20. 
36. Roper, Steven D. "Are All Semipresidential Regimes the Same: A Comparison of Premier-Presidential Regimes." Comparative Politics Vol. 34, No. 3 (2002): 253-272.

37. Samuels, David J., and Matthew S. Shugart. Presidents, Parties, and Prime Ministers: How Separation of Powers Affects Party Organization and Behavior. New York: Cambridge University Press, 2010.

38. Sedelius, Thomas. "Demokrati eller presidentdiktatur: Konstitutionella vägval i postkommunistiska länder." Nordisk Østforum Vol. 22, No. 8 (2008): 142161.

39. Sedelius, Thomas, and Olga Mashtaler. "A Troubled Tandem? Character and Issues of Intra-Executive Conflict under Semi-Presidentialism." Paper presented at the International Political Science Association's (IPSA) World Congress in Madrid (July 8-12, 2012).

40. Sedelius, Thomas, and Joakim Ekman. "Intra-executive Conflict and Cabinet Instability: Effects of Semi-Presidentialism in Central and Eastern Europe." Government and Opposition Vol. 45, No. 4 (2010): 505-30.

41. Sedelius, Thomas. The Tug-of-War between Presidents and Prime Ministers: Semi-Presidentialism in Central and Eastern Europe. Örebro: Örebro Studies in Political Science, 2006.

42. Siaroff, Alan. "Comparative Presidencies: The Inadequacy of the Presidential, Semi-Presidential and Parliamentary Distinction." European Journal of Political Research Vol. 42, No. 3 (2003): 287-313.

43. Shugart, Matthew S. "Semi-presidential Systems: Dual Executive and Mixed Authority Patterns." French Politics Vol. 3, No. 3 (2005): 323-51.

44. Shugart, Matthew S., and John M. Carey. Presidents and Assemblies: Constitutional Design and Electoral Dynamics. New York: Cambridge University Press, 2005.

45. Way, Lucan A. "Authoritarian State Building and the Sources of Regime Competitiveness in the Fourth Wave: The Case of Belarus, Moldova, Russia, and Ukraine." World Politics Vol. 57 (2005): 231-61.

46. Wise, Charles R., and Volodomyr Pigenko. "The Separation of Powers Puzzle in Ukraine": 25-55. In: Taras Kuzio et al., eds. State and Institution Building in Ukraine. New York: St. Martin's Press, 1999.

47. Wolczuk, Kataryna. "Ukraine: Tormented Constitution-Making": 243-268. In: Jan Zielonka, ed. Democratic Consolidation in Eastern Europe: Volume 1. Institutional Engineering. Oxford: Oxford University Press, 2001

48. Wolczuk, Kataryna. The Moulding of Ukraine: The Constitutional Politics of State Formation. Budapest: Central European University Press, 2001. 
49. Zaiotti, Ruben. "Of Friends and Fences: Europe's Neighbourhood Policy and the 'Gated Community Syndrome'." European Integration Vol. 29, No. 2 (2007): 143-162. 